\title{
Gender differences in knowledge and attitudes concerning induced abortion in Sri Lanka: a community based study in the Colombo City
}

\author{
M. Suchira Suranga ${ }^{1^{*}}$, Kalinga Tudor Silva ${ }^{2}$ and Lakshman Senanayake ${ }^{1}$ \\ ${ }^{I}$ The Family Planning Association of Sri Lanka, Colombo 07, Sri Lanka. \\ ${ }^{2}$ Emeritus Professor in Sociology, University of Peradeniya, Peradeniya, Sri Lanka.
}

\begin{abstract}
Abortion is legally permitted in Sri Lanka, only if it is performed to save the mother's life. However, it is estimated that 125,000 to 175,000 induced abortions take place annually (De Silva, 1997). Knowledge and attitudes towards induced abortion in society can influence individual decision-making on the outcome of unwanted pregnancies and the health sector policy response. This study aims to understand the gender differences in knowledge and attitudes of adults towards induced abortion in Sri Lanka. Six Grama Niladhari Divisions (GNDs) and 50 households in the Colombo City were systematically selected using multi stage cluster sampling. An interview schedule was administrated among 743 residents between 19 to 49 years of age after receiving their written informed consent. Around 31 percent of females and 57 percent of males do not know that there are specific days in the menstrual cycle in which the chance of becoming pregnant is relatively high. Female respondents' awareness (48 percent) of emergency contraception was significantly lower than that of males (60 percent). Only 11 percent of the respondents knew the situations in which abortion is legal in Sri Lanka. Around, 93 percent of females and 70 percent of males $\left(\mathrm{X}^{2}=56.27, \mathrm{P}<0.001\right)$ believed that induced abortion is against cultural and moral values. A majority of the respondents agreed to legalise abortion under rape (65 percent), incest (55 percent) and lethal fetal abnormality conditions (53 percent). A very small percentage of respondents agreed to legalise induced abortions in the situation of economic problems (7 percent), contraceptive failure ( 6 percent), at the request of the couple ( 5 percent) and at the request of the woman (4 percent). In conclusion, female respondents demonstrate a moderate to low level of knowledge and conservative attitudes towards induced abortion, which highlights the need for more focused interventions to address the issue.
\end{abstract}

Keywords: Induced abortion, knowledge, attitudes, gender.

\section{INTRODUCTION}

Abortion is the termination of a pregnancy, whether spontaneous or induced (Rock et al., 2008). Induced abortion is caused intentionally by the administration of drugs or by mechanical means (The American Heritage Stedman's Medical Dictionary, 2002). Illegal abortion is an induced abortion performed contrary to the laws regulating abortion in that country (Mosby's Medical Dictionary, 2009). According to World Health Organization (WHO), an unsafe abortion is the termination of an unintended pregnancy either by persons lacking the necessary skills or in an environment lacking the minimal medical standards or both (World Health Organization, n.d.). Globally, unsafe abortions are a significant cause of maternal mortality and morbidity. An estimated 21.6 million unsafe abortions took place worldwide in 2008 , almost all in developing countries. Each year an estimated 80,000 women die from complications of unsafe abortions, accounting for at least 13 percent of global maternal mortality (World Health Organization, 2011).

Abortion is legally permitted in Sri Lanka only if it is performed to save the mother's life (Sri Lanka Penal Code Section 303, 1883; Senanayake et al., 2012). Even with a high national contraceptive usage rate of 68 percent with 50 percent using modern methods, some women still face the problem of unwanted pregnancy and resort to abortion in Sri Lanka (Senanayake, 2009). As there is a very restrictive law on abortion and a law enforcement mechanism in the country, women will avoid divulging the fact and it is difficult to determine the accurate prevalence of illegal abortions. However, a study undertaken in the late 1990s estimated that 125,000 to 175,000 induced abortions, mostly illegal, are performed annually in Sri Lanka (De Silva, 1997). A subsequent study estimated a much higher figure of 658 induced abortions per day giving an abortion ratio of 741 per 1000 live births (Rajapakse, 2000). The latest study applying Bongaarts' model estimates induced abortion 
rate as $0.035,0.147$ and 0.087 per women in year 1993, 2000 and 2007, respectively (Abeykoon, 2012).

As illustrated in Table 1, contribution to maternal mortality is the most important consequence of septic abortion. In the year 2013, the percentage contribution from abortion to maternal mortality was around 10 percent, making it the third most common cause of maternal death (Family Health Bureau, 2014). Other negative impacts of illegal /unsafe abortion include, cost to the mothers (direct cost and indirect cost), cost to the state health system, psychological impact on the parents, family issues, social stigmatisation, loss of subsequent fertility as well as immediate post abortion complications leading to life threatening medical conditions. A recent study revealed that, the average cost (both direct and indirect) of an unsafe abortion that is incurred for procuring and thereafter managing the associated complications amounted to LKR 46,176 which consists of 79 percent of the health system cost (LKR 36,479), direct cost to the women (LKR 4,156) and indirect cost (LKR 5,541) to the women (Thalagala, 2010). Furthermore, a few studies conducted in selected groups indicate that about 12 to 14 percent of abortion seekers in Sri Lanka experienced some form of medical complication following abortion (Perera et al., 2004).

It is not only the burden of illegal abortion; almost all health related issues are inevitable consequences of socio-economic perspectives of communities in the world. Health systems, health programmes, and health policies of any country need to be developed taking in to consideration social perceptions, attitudes, and values of the people.
Although there is very limited research based evidence on abortion related knowledge and attitudes in Sri Lanka, a few previous studies have focused on abortion knowledge and attitudes of targeted sub segments of the community. Less than 20 percent of abortion seekers felt that there could be complications due to induced abortions (Rajapakshe \& De Silva, 2000). Comparatively higher proportion (96 percent) of abortion seekers in Colombo district were aware of possible long term consequences of abortion such as pelvic inflammatory disease and sub fertility (Perera, et al., 2004). The awareness of complications of unsafe abortion was lower among abortion seekers ( 83.1 percent) when compared to the women who do not have a history of abortion (92.1 percent). However, a relatively higher proportion of women who have history of abortion (22.9 percent) had heard of a women who had experienced complications following an abortion when compared with women with wanted pregnancies (14.4 percent) (Thalagala, 2010). The proportion of those who were aware of the current abortion law among women with unwanted pregnancies (69.5 percent) was lower when compared to the women who have undergone an abortion (74.4 percent) and women with wanted pregnancies (80.4 percent) (Thalagala, 2010).

Less than half (43 percent) of abortion seekers felt that abortion services should be available on demand, especially for unmarried women, and approved the liberalisation (45.9 percent) of the abortion law. Among those who approved the liberalisation, only 27 percent approved such liberalisation for both married and unmarried women (Rajapakshe \& De Silva, 2000).

Table 1: Rate of maternal mortality and causes of maternal mortality in Sri Lanka

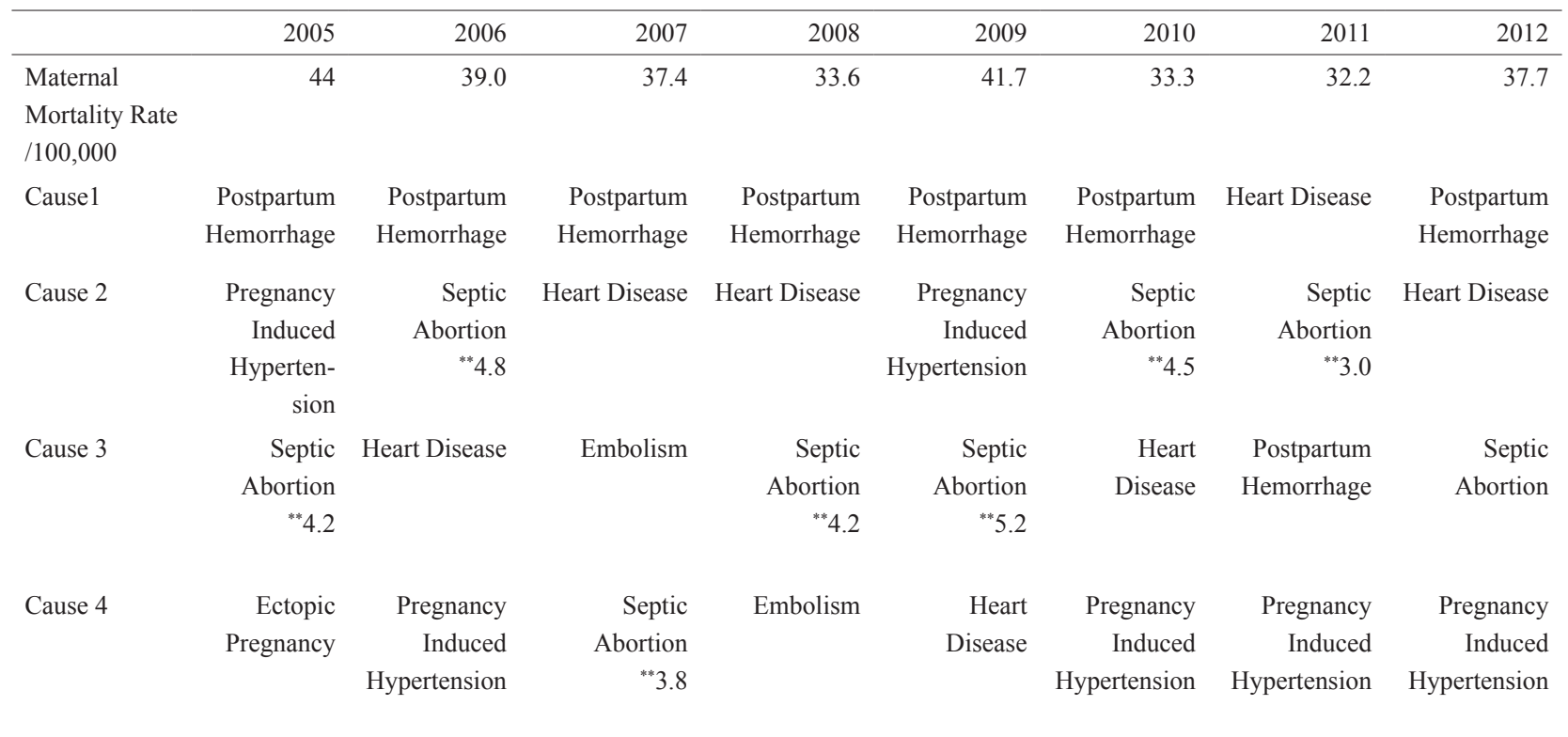

${ }^{* *}$ Cause specific maternal mortality rate for abortion (per 100,000)

Source: Family Health Bureau Annual Reports (2005-2012) 
Only 23 percent of women with a history of abortion, 15 percent of women with unwanted pregnancies and even less proportion (10 percent) of women with wanted pregnancies felt that legalising abortion will be beneficial to women (Thalagala, 2010). A qualitative study conducted by a group of researchers on knowledge attitudes and understanding of 25 legal professionals regarding safe abortion as a women's right, found that the majority $(22 / 25)$ were either vehemently opposed on cultural and moral grounds or had some reservations about health implications for women. They said that legalising abortions would promote irresponsible behavior; the government may not be able to fulfill the demands and there would be cultural and moral clashes (Dalvie et al., n.d.). However, almost all doctors (93 percent) and four fifth of (81 percent) of medical students accepted pregnancy termination as an appropriate course of action if a gross genetic defect is detected antenatal. Furthermore, 87 percent of doctors and 80 percent of students supported a change to the law allowing for termination of a pregnancy (Senanayake et al., 2008). In addition to the above findings, Hewage (1999) conducted a research on opinions of health professionals on induced abortion in Sri Lanka and paid attention to all health professionals who have direct access to cases of induced abortion in their professional work (Hewage, 1999).

None of the previous studies focused on the knowledge and attitudes of the general public concerning induced abortion in Sri Lankan context using a representative sample (Kaluaarachchi et al., 2016; Abeykoon, 2012; Arambepola \& Rajapakshe, 2014; De Silva, 1997; Hewage, 1999; Perera et al., 2004; Senanayake, 2009; Simpson, et al., 2003; Thalagala, 2010; Wickramasinghe et al., 2009). Although there are many historical research on gender differences in abortion knowledge and attitudes in other countries (Walzer, 1994; Cater et al., 2009; Lucinda \& Cynthia, 2009; Finlay, 1981; Narendra, 2010), it is very rare in the Sri Lankan context (Senanayake et al., 2008). After reviewing past studies in the global context, Narendra (2010) argued whether sex affects abortion attitudes are inconsistent and yield diverse results under different social settings.

General societal knowledge and attitudes towards induced abortion can influence not only decisionmaking by individuals regarding the fate of unwanted pregnancies, but also the health sector policy response towards providing safe abortion services (Arambepola \& Rajapakshe, 2014; Thalagala, 2010).

This study is expected to address the above knowledge gap and aims to understand knowledge and attitudes of adults towards induced abortion and abortion law in Sri Lanka with special focus on gender differences. The authors feel that the results of this study will assist the Sri Lankan government and other development agencies in developing health policies and programmes.

\section{METHODOLOGY}

The population selected for this study included all adults, aged 19 to 49 who have lived in Colombo city for at least one year. Both males and females were included in the study as previous studies show that both males and females are involved in the decision making process on outcome of the unwanted pregnancies (Thalagala, 2010; Arambepola \& Rajapakshe, 2014). This age group was selected to represent youth and adults. The pre-dominant age group vulnerable for unsafe abortion in Sri Lanka is 25 to 29 followed by 30 to 34 (Senanayake et al., 2008). Both age groups were captured in this study. However, considering the nature of the questions, study setting (at households) and ethical aspects, youth who are below 19 years of age were not included. Results of the previous studies indicate that the abortion seekers who are in the age group below 19 years were very small, ranging from 2.0 to 8.6 percent (Senanayake et al., 2008). Since the age of first intercourse and age of first marriage is higher in Sri Lanka in comparison to other Asian countries (Department of Censes and Statistics, 2009), majority under the age of 19 are assumed to be unmarried young people who do not have sexual experiences. The Colombo city was selected for the study, as the highest rate of abortion is estimated in Colombo city (De Silva, 1997) and it represents a fair distribution of all ethnic groups (Department of Census and Statistics, 2012).

The study was conducted in Thimbirigasyaya Divisional Secretariat Division (DSD). The 20 Grama Niladhari Divisions (GND) of Thimbirigasyaya DSD was divided into two strata considering the percentage of households with toilet facilities within the household. First stratum contained 10 GNDs which reported more than 80 percent of households with toilet facilities within the household unit, whereas second stratum contained 10 GNDs which reported less than 80 percent of households with toilet facilities within the household unit. Three GNDs were selected from each stratum (total of six GNDs) using systematic probability proportionate to the size (PPS) and cluster selection method. The population and housing data available in the Department of Census and Statistics website were used for stratification and for selection of GNDs (Department of Census and Statistics, 2012). The selected GNDs were divided into housing clusters using the housing data derived from the 2012 Department of Election report (Department of Election, 2012). Five to eight housing clusters were selected from each GND by following the systematic PPS cluster selection method. In total, 50 households were selected 
from each GND. Starting from a random point, every third household was selected for the survey until the expected sample size was attained. The primary sample size for the household survey was 300 households which was arrived by application of a standard sample size calculation formula for household surveys (Department of Economic and Social Affairs, Statistics Division, United Nations Secretariat, 2005). All the eligible individuals who were willing to participate in the survey were interviewed after receiving written informed consent. Apart from the household survey, 12 key informants (Health Professionals and Community Health Service Providers) were selected to identify possible interventions to address the issue. The Ethical Approval was received from the Ethical Review Committee of the Sri Lanka Medical Association. A structured questionnaire was administered by a team of well-trained survey staff who were recruited from among Sociology Special graduates of University of Colombo. The key informant interviews were conducted by the Principle Investigator. Field data collection was conducted from February to April 2014. The data was analysed using SPSS software.

\section{RESULTS AND DISCUSSION}

This research obtained at least one response from 271 households out of 300 selected households. The remaining households had no person eligible to participate in the study or they were not willing to participate in the study. There were 1,022 eligible people residing in the 271 households surveyed. However, only 825 participants (80.72 percent) were available for the interview on the date of the visit. A total of 743 valid responses $(90.06$ percent) was received.

\section{Profile of the respondents}

The average age of the respondents was 33 years $(\mathrm{SD}=$ 11.15). The sample consists of 305 (41.22 percent) males and 435 (58.78 percent) females. The average household size of the sample was 5.46 per household. The ethnic composition of the sample was 384 (51.68 percent) Sinhalese, 131 (17.63 percent) Muslims, and 221 (29.74 percent) Tamils. Similarly, the sample contained 316 (42.53 percent) Buddhists, 136 (18.30 percent) Muslims, 165 (22.21 percent) Hindus, 50 (6.73 percent) Roman Catholics and 76 (10.23 percent) Christians. Approximately, 71.53 percent of the participants have received education up to the General Certificate of Education (GCE) Ordinary Level $(\mathrm{O} / \mathrm{L})$ or above with average years of formal education of $11.20(\mathrm{SD}=2.75)$ years ranging from 2 years to 19 years. Around 53.44 percent of the respondents were married and the mean age at first marriage was $24.36(n=420, S D=3.25)$ with the range of 18 years to 41 years.

\section{Level of knowledge on sexuality, pregnancy, contraception and abortion}

As described in Table 2, the respondents demonstrated average to fairly good level of knowledge on pregnancy, overcoming unwanted pregnancies and prevalence of illegal abortion in Sri Lanka. However, the respondents' awareness of the current abortion law in Sri Lanka was relatively low. Around 31 percent of females and 57 percent of males do not know that there are specific days in the menstrual cycle in which the chance of becoming pregnant is relatively high. Surprisingly, even around 25 percent of ever married women are not aware of this matter. One out of two respondents (52 percent) believed that intercrural intercourse without insertion in to vagina will not result in a pregnancy. This segment of society is more vulnerable to unwanted pregnancies and unsafe abortions. Overall, male respondents shows a lower level of awareness on the matters related to pregnancy.

Respondents' knowledge on contraception and emergency contraception was considered to be average. However, female respondents' awareness (48 percent) of emergency contraception was significantly lower than that of males ( 60 percent). This can be considered as one of the significant findings of this study. Also, the female respondents showed a lower level of awareness on the effective time period of emergency contraceptives compared to male respondents. Only 51 percent of ever married women were aware of emergency contraceptives. Around 45 percent of respondents were unaware that even the modern contraceptive methods have a failure rate.

Respondent's demonstrated a fairly good awareness of complications and prevalence of induced abortions (Table 3). Around 81 percent of females and 91 percent of males were aware that illegal abortions can result in many complications including death. However, female respondents' awareness on complications of illegal abortion is significantly low $\left(\mathrm{X}^{2}=15.337, \mathrm{P}<0.001\right)$. Although, the illegal abortion is a matter which is directly related to the women's health, female respondents' awareness of the conditions in which illegal abortion occurs in Sri Lanka is significantly lower than those of males. Around 65 percent of respondents think that a majority of Sri Lankan women who undergo illegal abortion are unmarried youth, having premarital sex. This view is more prevalent among female respondents (73 percent) than male respondents ( 55 percent $)\left(X^{2}=25.313\right.$, $\mathrm{P}<0.001)$. This misconception in the community may result in an increase in risk taking behaviors and vulnerability among married couples in seeking illegal abortions. One of the important findings of this study is that, the level of awareness on illegal abortions among 
Table 2 : Respondents level of knowledge on pregnancy and overcoming unwanted pregnancies, disaggregated by gender

\begin{tabular}{|c|c|c|c|c|c|c|c|c|}
\hline \multirow[t]{5}{*}{ Statement } & \multicolumn{6}{|c|}{ Number $(\mathrm{N})$ and percentage $(\%)$ of correct answers } & \multirow{5}{*}{$\begin{array}{r}\text { Chi-squre } \\
\text { test for } \\
\text { association }\end{array}$} & \multirow{5}{*}{$\begin{array}{r}\text { Effect size } \\
(\text { Phi or } \\
\text { cremer's V) }\end{array}$} \\
\hline & \multicolumn{4}{|c|}{ Sex } & \multirow{2}{*}{\multicolumn{2}{|c|}{ Total }} & & \\
\hline & \multicolumn{2}{|c|}{ Female } & \multicolumn{2}{|c|}{ Male } & & & & \\
\hline & $\mathrm{N}$ & $\%$ & $\mathrm{~N}$ & $\%$ & \multirow[t]{2}{*}{$\mathrm{N}$} & \multirow{2}{*}{$\begin{array}{r}\% \\
(\mathrm{n}=740) \\
\end{array}$} & & \\
\hline & & $(n=435)$ & & $(n=305)$ & & & & \\
\hline $\begin{array}{l}\text { A girl has a chance of becoming pregnant after a } \\
\text { sexual act even before the first menstruation }\end{array}$ & 259 & $60 \%$ & 155 & $51 \%$ & 414 & $56 \%$ & $\begin{array}{l}\mathrm{X}^{2}=5.532 \\
\mathrm{P}=0.019^{*}\end{array}$ & $\begin{aligned} \mathrm{Phi} & =-0.086 \\
\mathrm{P} & =0.019\end{aligned}$ \\
\hline $\begin{array}{l}\text { A girl or woman can become pregnant by follow- } \\
\text { ing an Intercrural sexual act }\end{array}$ & 222 & $51 \%$ & 135 & $44 \%$ & 357 & $48 \%$ & $\begin{aligned} \mathrm{X}^{2} & =3.293 \\
\mathrm{P} & =0.070\end{aligned}$ & $\mathrm{~N} / \mathrm{A}$ \\
\hline $\begin{array}{l}\text { There are specific days in the menstrual cycle } \\
\text { where the likelihood of becoming pregnant is } \\
\text { relatively high }\end{array}$ & 299 & $69 \%$ & 132 & $43 \%$ & 431 & $58 \%$ & $\begin{aligned} \mathrm{X}^{2} & =47.775 \\
\mathrm{P} & =0.000^{* *}\end{aligned}$ & $\begin{aligned} \mathrm{Phi} & =-0.254 \\
\mathrm{P} & =0.000^{*}\end{aligned}$ \\
\hline $\begin{array}{l}\text { Any modern contraceptive method is not } 100 \\
\text { percent secure in preventing a pregnancy }\end{array}$ & 242 & $56 \%$ & 166 & $54 \%$ & 408 & $55 \%$ & $\begin{array}{r}\mathrm{X}^{2}=0.105 \\
\mathrm{P}=0.745\end{array}$ & $\mathrm{~N} / \mathrm{A}$ \\
\hline $\begin{array}{l}\text { There are some drugs which can be taken even } \\
\text { after an unsafe sexual encounter to avoid a } \\
\text { pregnancy }\end{array}$ & 209 & $48 \%$ & 237 & $78 \%$ & 446 & $60 \%$ & $\begin{aligned} \mathrm{X}^{2} & =65.864 \\
\mathrm{P} & =0.000^{* *}\end{aligned}$ & $\begin{array}{l}\mathrm{Phi}=0.298 \\
\mathrm{P}=0.000^{*}\end{array}$ \\
\hline $\begin{array}{l}\text { Emergency contraceptives must be taken within } 7 \\
\text { days after an unsafe sexual encounter in order to } \\
\text { avoid an unwanted pregnancy }\end{array}$ & 143 & $33 \%$ & 190 & $62 \%$ & 333 & $45 \%$ & $\begin{aligned} \mathrm{X}^{2} & =62.706 \\
\mathrm{P} & =0.000^{* *}\end{aligned}$ & $\begin{array}{l}\mathrm{Phi}=0.291 \\
\mathrm{P}=0.000^{*}\end{array}$ \\
\hline
\end{tabular}

* Statistically significant at $95 \%$ confidence interval

${ }^{* *}$ Statistically significant at $99 \%$ confidence interval

Table 3 : Respondents level of knowledge on illegal abortions and associated consequences, disaggregated by gender

\begin{tabular}{|c|c|c|c|c|c|c|c|c|}
\hline \multirow[t]{4}{*}{ Statement } & \multicolumn{6}{|c|}{ Number $(\mathrm{N})$ and percentage $(\%)$ of correct answers } & \multirow{4}{*}{$\begin{array}{r}\text { Chi-squre } \\
\text { test for } \\
\text { association }\end{array}$} & \multirow{4}{*}{$\begin{array}{r}\text { Effect size } \\
\text { (Phi or } \\
\text { cremer's V) }\end{array}$} \\
\hline & \multicolumn{4}{|c|}{ Sex } & \multirow{2}{*}{\multicolumn{2}{|c|}{ Total }} & & \\
\hline & \multicolumn{2}{|c|}{ Female } & \multicolumn{2}{|c|}{ Male } & & & & \\
\hline & $\mathrm{N}$ & $\begin{array}{r}\% \\
(\mathrm{n}=435)\end{array}$ & $\mathrm{N}$ & $\begin{array}{r}\% \\
(\mathrm{n}=305)\end{array}$ & $\mathrm{N}$ & $\begin{array}{r}\% \\
(\mathrm{n}=740)\end{array}$ & & \\
\hline $\begin{array}{l}\text { Illegal abortions can result in many complications } \\
\text { including death }\end{array}$ & 353 & $81 \%$ & 279 & $91 \%$ & 632 & $85 \%$ & $\begin{aligned} \mathrm{X}^{2} & =15.337 \\
\mathrm{P} & =0.000^{* *}\end{aligned}$ & $\begin{array}{l}\mathrm{Phi}=0.144 \\
\mathrm{P}=0.000^{* *}\end{array}$ \\
\hline $\begin{array}{l}\text { Since abortion is illegal, it is not taking place in } \\
\text { Sri Lanka }\end{array}$ & 372 & $86 \%$ & 234 & $77 \%$ & 606 & $82 \%$ & $\begin{array}{l}\mathrm{X}^{2}=9.354 \\
\mathrm{P}=0.002^{* *}\end{array}$ & $\begin{aligned} \mathrm{Phi} & =-0.112 \\
\mathrm{P} & =0.002^{* *}\end{aligned}$ \\
\hline $\begin{array}{l}\text { The most common reason mentioned by the ille- } \\
\text { gal abortion seekers in Sri Lanka is to terminate } \\
\text { the first pregnancy after the marriage. }\end{array}$ & 100 & $23 \%$ & 184 & $60 \%$ & 284 & $38 \%$ & $\begin{aligned} X^{2} & =105.699 \\
P & =0.000^{* *}\end{aligned}$ & $\begin{array}{l}\mathrm{Phi}=0.378 \\
\mathrm{P}=0.000^{* *}\end{array}$ \\
\hline $\begin{array}{l}\text { Majority of Sri Lankan women who undergo } \\
\text { illegal abortions are unmarried youth who were } \\
\text { having premarital sex. }\end{array}$ & 119 & $27 \%$ & 138 & $45 \%$ & 257 & $35 \%$ & $\begin{aligned} \mathrm{X}^{2} & =25.313 \\
\mathrm{P} & =0.000^{* *}\end{aligned}$ & $\begin{array}{l}\mathrm{Phi}=0.185 \\
\mathrm{P}=0.000^{* *}\end{array}$ \\
\hline
\end{tabular}

${ }^{*}$ Statistically significant at $95 \%$ confidence interval

** Statistically significant at $99 \%$ confidence interval 
Table 4 : Respondents level of knowledge on current abortion law, disaggregated by gender

\begin{tabular}{|c|c|c|c|c|c|c|c|c|}
\hline \multirow[t]{4}{*}{ Statement } & \multicolumn{6}{|c|}{ Number $(\mathrm{N})$ and percentage $(\%)$ of correct answers } & \multirow{4}{*}{$\begin{array}{r}\text { Chi-squre } \\
\text { test for } \\
\text { association }\end{array}$} & \multirow{4}{*}{$\begin{array}{r}\text { Effect size } \\
\text { (Phi or } \\
\text { cremer's V) }\end{array}$} \\
\hline & \multicolumn{4}{|c|}{ Sex } & \multirow{2}{*}{\multicolumn{2}{|c|}{ Total }} & & \\
\hline & \multicolumn{2}{|c|}{ Female } & \multicolumn{2}{|c|}{ Male } & & & & \\
\hline & $\mathrm{N}$ & $\begin{array}{r}\% \\
(n=435) \\
\end{array}$ & $\mathrm{N}$ & $\begin{array}{r}\% \\
(n=305) \\
\end{array}$ & $\mathrm{N}$ & $\begin{array}{r}\% \\
(\mathrm{n}=740) \\
\end{array}$ & & \\
\hline $\begin{array}{l}\text { Induced abortion is legal in Sri Lanka under some } \\
\text { circumstances }\end{array}$ & 175 & $40 \%$ & 76 & $25 \%$ & 251 & $34 \%$ & $\begin{array}{l}\mathrm{X}^{2}=18.754 \\
\mathrm{P}=0.000^{* *}\end{array}$ & $\begin{aligned} \mathrm{Phi} & =-0.159 \\
\mathrm{P} & =0.000^{* *}\end{aligned}$ \\
\hline $\begin{array}{l}\text { In which of the following situations is induced } \\
\text { abortion legal in Sri Lanka? }\end{array}$ & 64 & $15 \%$ & 17 & $6 \%$ & 81 & $11 \%$ & $\begin{array}{l}\mathrm{X}^{2}=15.362 \\
\mathrm{P}=0.000^{* *}\end{array}$ & $\begin{aligned} \mathrm{Phi} & =-0.144 \\
\mathrm{P} & =0.000^{* *}\end{aligned}$ \\
\hline $\begin{array}{l}\text { Provision of treatment for a woman who has gone } \\
\text { through an illegal abortion is an offence as per } \\
\text { the present abortion law }\end{array}$ & 117 & $27 \%$ & 67 & $22 \%$ & 184 & $25 \%$ & $\begin{array}{r}\mathrm{X}^{2}=2.332 \\
\mathrm{P}=0.127\end{array}$ & $\mathrm{~N} / \mathrm{A}$ \\
\hline $\begin{array}{l}\text { A pregnant women can get free safe abortion } \\
\text { services from a government hospital, if the } \\
\text { medical condition she has due tothe pregnancy is } \\
\text { considered as a threat to her life }\end{array}$ & 63 & $14 \%$ & 36 & $12 \%$ & 99 & $13 \%$ & $\begin{aligned} \mathrm{X} 2 & =1.111 \\
\mathrm{P} & =0.232\end{aligned}$ & N/A \\
\hline
\end{tabular}

* Statistically significant at $95 \%$ confidence interval

${ }^{* *}$ Statistically significant at $99 \%$ confidence interval

the women over the age of 25 years was relatively higher than awareness of girls under the age of 25 years. This shows that the knowledge on abortion develops with life experiences over time than formal education in schools or out of school.

Respondents' knowledge on current legal status of abortion in Sri Lanka was considerably low (Table 4). Less than one third of the respondents provided accurate answers to the questions related to current law on abortion. Only 11 percent of the respondents knew the situations in which abortion is legal in Sri Lanka. Around two third (66 percent) of respondents believed abortion is not legal under any circumstance. Around 14 percent of the respondents believed that abortion is legal in Sri Lanka for rape, incest and fetal abnormalities. Similarly, around 12 percent of respondents believed abortion is legal in Sri Lanka to protect mental or physical health of the mother. Only two respondents believed that abortion is legal in Sri Lanka for every situation. Three fourth of respondents (73 percent of females and 68 percent of males) thought that provision of treatment for a woman who has undergone an illegal abortion is an offence as per the current law on abortion. This misconception may lead to delay in accessing treatment for complications after an abortion resulting in high rate of maternal mortality due to unsafe abortions. One of the interesting findings of this study is that female respondents demonstrated a higher level of awareness on all the aspects related to law on abortion compared to male respondents.

\section{Attitudes towards induced abortion}

As illustrated in Table 5, respondents demonstrated diverse attitudes towards different aspects related to induced abortion. A majority (87 percent of females and 96 percent of males) agreed that issues relating to unsafe abortion must be taught to young children by their teachers and parents to reduce the number of incidence, showing a significant gender differences in their attitudes $\left(X^{2}=8.123, P=0.004\right)$. Similarly, around 25 percent of female and 16 percent of males believe that, since abortion is legally restricted in Sri Lanka, people must not even talk about this issue. Confirming the above pattern of gender differences in abortion attitudes, 94 percent of females and 68 percent of males $\left(X^{2}=70.334\right.$, $\mathrm{P}<0.001)$ stated that induced abortion is against their religious beliefs. Similarly, 93 percent of females and 70 percent of males $\left(\mathrm{X}^{2}=56.27, \mathrm{P}<0.001\right)$ held that induced abortion is against cultural and moral values that they accept. Around 46 percent of the respondents stated that the service providers who provide illegal abortion services have no ethical or moral values. This reflects the high level of stigma on induced abortion prevailing in the country. The results indicate that attitudes of the male respondents are significantly different from those of female respondents for almost all aspects (seven out of nine aspects considered). Female respondents demonstrated conservative attitudes on induced abortion when compared to male respondents. Exploring gender differences in abortion attitudes, this study further examined the acceptance of possible changes to the current law on abortion in Sri Lanka. 
Table 5: Respondents' general attitudes towards abortion, disaggregated by gender

\begin{tabular}{|c|c|c|c|c|c|c|c|c|}
\hline \multirow[t]{3}{*}{ Statement } & \multirow[t]{3}{*}{ Levels } & \multicolumn{4}{|c|}{ Sex } & \multicolumn{2}{|c|}{ Total } & \multirow{3}{*}{$\begin{array}{l}\text { Chi-squire } \\
\text { test for } \\
\text { indepen- } \\
\text { dency }\end{array}$} \\
\hline & & \multicolumn{2}{|c|}{ Female } & \multicolumn{2}{|c|}{ Male } & & & \\
\hline & & $\mathrm{N}$ & $\%$ & $\mathrm{~N}$ & $\%$ & & & \\
\hline 1) Since abortion is restricted in & Agree or Strongly agree & 102 & $25 \%$ & 44 & $16 \%$ & 146 & $20 \%$ & $\mathrm{X} 2=8.123$ \\
\hline Sri Lanka, we must not even talk & Disagree or Strongly disagree & 301 & $75 \%$ & 229 & $84 \%$ & 530 & $72 \%$ & $\mathrm{P}=0.004^{* *}$ \\
\hline about this matter & Subtotal & 403 & $100 \%$ & 273 & $100 \%$ & 676 & $91 \%$ & \\
\hline 2) Issues related to unsafe abortions & Agree or Strongly agree & 367 & $87 \%$ & 267 & $96 \%$ & 634 & $86 \%$ & $\mathrm{X} 2=16.477$ \\
\hline and its consequences should be taught & Disagree or Strongly disagree & 53 & $13 \%$ & 10 & $4 \%$ & 63 & $9 \%$ & $\mathrm{P}=0.000^{* *}$ \\
\hline $\begin{array}{l}\text { in schools to reduce the number of } \\
\text { incidences }\end{array}$ & Subtotal & 420 & $100 \%$ & 277 & $100 \%$ & 697 & $94 \%$ & \\
\hline 3) Parents must educate their young & Agree or Strongly agree & 377 & $90 \%$ & 269 & $97 \%$ & 646 & $87 \%$ & $X 2=13.861$ \\
\hline children on unsafe abortion to reduce & Disagree or Strongly disagree & 44 & $10 \%$ & 8 & $3 \%$ & 52 & $7 \%$ & $\mathrm{P}=0.000^{* *}$ \\
\hline the number of incidences. & Subtotal & 421 & $100 \%$ & 277 & $100 \%$ & 698 & $94 \%$ & \\
\hline 4) Legalising abortion on demand & Agree or Strongly agree & 248 & $70 \%$ & 209 & $89 \%$ & 457 & $62 \%$ & $\mathrm{X} 2=30.179$ \\
\hline may promote sexual promiscuity. & Disagree or Strongly disagree & 106 & $30 \%$ & 25 & $11 \%$ & 131 & $18 \%$ & $\mathrm{P}=0.000^{* *}$ \\
\hline & Subtotal & 354 & $100 \%$ & 234 & $100 \%$ & 588 & $79 \%$ & \\
\hline 5) Abortion services are not usually & Agree or Strongly agree & 180 & $54 \%$ & 91 & $54 \%$ & 271 & $37 \%$ & $\mathrm{X} 2=0.000$ \\
\hline required for married women. & Disagree or Strongly disagree & 154 & $46 \%$ & 78 & $46 \%$ & 232 & $31 \%$ & $\mathrm{P}=0.992$ \\
\hline & Subtotal & 334 & $100 \%$ & 169 & $100 \%$ & 503 & $68 \%$ & \\
\hline 6) Economic difficulties cannot & Agree or Strongly agree & 248 & $69 \%$ & 108 & $55 \%$ & 356 & $48 \%$ & $X 2=10.473$ \\
\hline be used as a reason for justitying & Disagree or Strongly disagree & 112 & $31 \%$ & 88 & $45 \%$ & 200 & $27 \%$ & $\mathrm{P}=0.001^{* *}$ \\
\hline abortion services. & Subtotal & 360 & $100 \%$ & 196 & $100 \%$ & 556 & $75 \%$ & \\
\hline 7) Induced abortion is against my & Agree or Strongly agree & 375 & $94 \%$ & 141 & $68 \%$ & 516 & $70 \%$ & $\mathrm{X} 2=70.334$ \\
\hline religious belief. & Disagree or Strongly disagree & 25 & $06 \%$ & 66 & $32 \%$ & 91 & $12 \%$ & $\mathrm{P}=0.000^{* *}$ \\
\hline & Subtotal & 400 & $100 \%$ & 207 & $100 \%$ & 607 & $82 \%$ & \\
\hline 8) Induced abortion is against cultural & Agree or Strongly agree & 366 & $93 \%$ & 147 & $70 \%$ & 513 & $69 \%$ & $\mathrm{X} 2=56.273$ \\
\hline and moral values that I accept. & Disagree or Strongly disagree & 27 & $07 \%$ & 62 & $30 \%$ & 89 & $12 \%$ & $\mathrm{P}=0.000^{* *}$ \\
\hline & Subtotal & 393 & $100 \%$ & 209 & $100 \%$ & 602 & $81 \%$ & \\
\hline 9) Service providers who provide ille- & Agree or Strongly agree & 217 & $67 \%$ & 126 & $65 \%$ & 343 & $46 \%$ & $\mathrm{X} 2=0.180$ \\
\hline gal abortion services have no ethical & Disagree or Strongly disagree & 108 & $33 \%$ & 68 & $35 \%$ & 176 & $24 \%$ & $\mathrm{P}=0.672$ \\
\hline and moral values. & Subtotal & 325 & $100 \%$ & 194 & $100 \%$ & 519 & $70 \%$ & \\
\hline
\end{tabular}

${ }^{* *}$ Statistically significant at $99 \%$ confidence interval

\section{Attitudes concerning provisions within the abortion law}

As evident in Table 6, approximately one tenth of the respondents (11 percent) do not accept provisions of the current abortion law to perform induced abortion; that is to save the life of the mother. A majority of the respondents agreed to legalise abortion under rape (65 percent), incest (55 percent) and lethal fetal abnormality conditions (53 percent). However, only 30 percent of the respondents accept abortion under the situations of fetal abnormalities, but the fetus / child is expected to survive with severe abnormalities. A very small percentage of respondents would legalise induced abortions in the situation of economic problems (7 percent), contraceptive failure (6 percent), at the request of the couple ( 5 percent) and at the request of the woman (4 percent). These results highlight that the respondents are more likely to accept legalising abortion in situations where the cause of the pregnancy is completely beyond the control of the woman.

Interestingly, there is no statistically significant difference between males and females on their level of acceptance for legalising abortion under the conditions of rape, incest or to save the life of the mother. However, although the numbers are small, more females are likely to support legalising abortion than males in situations of 
Table 6: Respondents' attitudes towards the current abortion law and possible changes to the abortion law, disaggregated by gender

\begin{tabular}{|c|c|c|c|c|c|c|c|c|}
\hline \multirow[t]{3}{*}{ Statement } & \multirow[t]{3}{*}{ Levels } & \multicolumn{4}{|c|}{ Gender } & \multirow{2}{*}{\multicolumn{2}{|c|}{ Total }} & \multirow{3}{*}{$\begin{array}{r}\text { Chi-squire } \\
\text { test for } \\
\text { indepen- } \\
\text { dency }\end{array}$} \\
\hline & & \multicolumn{2}{|c|}{ Female } & \multicolumn{2}{|c|}{ Male } & & & \\
\hline & & $\mathrm{N}$ & $\%$ & $\mathrm{~N}$ & $\%$ & $\mathrm{~N}$ & $\begin{array}{r}\% \\
(\mathrm{n}=740)\end{array}$ & \\
\hline 1) Government of Sri Lanka must & Agree or Strongly agree & 45 & $11 \%$ & 37 & $14 \%$ & 82 & $11 \%$ & $\mathrm{X} 2=1.409$ \\
\hline not legalise abortion under any & Disagree or Strongly disagree & 380 & $89 \%$ & 236 & $86 \%$ & 616 & $83 \%$ & $\mathrm{P}=0.235$ \\
\hline circumstance & Subtotal & 425 & $100 \%$ & 273 & $100 \%$ & 698 & $94 \%$ & \\
\hline 2) Government of Sri Lanka must & Agree or Strongly agree & 381 & $89 \%$ & 240 & $89 \%$ & 621 & $84 \%$ & $\mathrm{X} 2=0.052$ \\
\hline legalise abortion to save the mothers' & Disagree or Strongly disagree & 45 & $11 \%$ & 30 & $11 \%$ & 75 & $10 \%$ & $\mathrm{P}=0.820$ \\
\hline life & Subtotal & 426 & $100 \%$ & 270 & $100 \%$ & 696 & $94 \%$ & \\
\hline 3) Government of Sri Lanka must & Agree or Strongly agree & 297 & $73 \%$ & 186 & $76 \%$ & 483 & $65 \%$ & $\mathrm{X} 2=0.711$ \\
\hline legalise abortion to terminate preg- & Disagree or Strongly disagree & 112 & $27 \%$ & 60 & $24 \%$ & 172 & $23 \%$ & $\mathrm{P}=0.399$ \\
\hline nancy resulting in a rape case & Subtotal & 409 & $100 \%$ & 246 & $100 \%$ & 655 & $89 \%$ & \\
\hline 4) Government of Sri Lanka must & Agree or Strongly agree & 248 & $62 \%$ & 158 & $68 \%$ & 406 & $55 \%$ & $\mathrm{X} 2=3.000$ \\
\hline legalise abortion to terminate preg- & Disagree or Strongly disagree & 155 & $38 \%$ & 73 & $32 \%$ & 228 & $31 \%$ & $\mathrm{P}=0.083$ \\
\hline nancy resulting from incest & Subtotal & 403 & $100 \%$ & 231 & $100 \%$ & 634 & $86 \%$ & \\
\hline 5) Government of Sri Lanka must & Agree or Strongly agree & 224 & $56 \%$ & 168 & $69 \%$ & 392 & $53 \%$ & $\mathrm{X} 2=10.054$ \\
\hline legalise abortion to terminate a & Disagree or Strongly disagree & 174 & $44 \%$ & 76 & $31 \%$ & 250 & $34 \%$ & $\mathrm{P}=0.002^{* *}$ \\
\hline $\begin{array}{l}\text { pregnancy with fetal abnormalities - } \\
\text { lethal condition. }\end{array}$ & Subtotal & 398 & $100 \%$ & 244 & $100 \%$ & 642 & $87 \%$ & \\
\hline 6) Government of Sri Lanka must & Agree or Strongly agree & 142 & $37 \%$ & 80 & $37 \%$ & 222 & $3 \%$ & $\mathrm{X} 2=0.000$ \\
\hline legalise abortion to terminate a preg- & Disagree or Strongly disagree & 239 & $63 \%$ & 135 & $63 \%$ & 374 & $51 \%$ & $\mathrm{P}=0.988$ \\
\hline $\begin{array}{l}\text { nancy with fetal abnormalities - fetus } \\
\text { may survive }\end{array}$ & Subtotal & 381 & $100 \%$ & 215 & $100 \%$ & 596 & $81 \%$ & \\
\hline 7) Government of Sri Lanka must & Agree or Strongly agree & 35 & $9 \%$ & 11 & $5 \%$ & 46 & $6 \%$ & $\mathrm{X} 2=4.118$ \\
\hline legalise abortion to terminate a preg- & Disagree or Strongly disagree & 360 & $91 \%$ & 230 & $95 \%$ & 590 & $80 \%$ & $\mathrm{P}=0.042^{*}$ \\
\hline $\begin{array}{l}\text { nancy resulting from a contraceptive } \\
\text { failure. }\end{array}$ & Subtotal & 395 & $100 \%$ & 241 & $100 \%$ & 636 & $86 \%$ & \\
\hline 8) Government of Sri Lanka must & Agree or Strongly agree & 42 & $10 \%$ & 8 & $3 \%$ & 50 & $7 \%$ & $\mathrm{X} 2=11.582$ \\
\hline legalise abortion to terminate a preg- & Disagree or Strongly disagree & 365 & $90 \%$ & 247 & $97 \%$ & 612 & $83 \%$ & $\mathrm{P}=0.001^{* *}$ \\
\hline $\begin{array}{l}\text { nancy on account of bad economic } \\
\text { conditions of the family }\end{array}$ & Subtotal & 407 & $100 \%$ & 255 & $100 \%$ & 662 & $89 \%$ & \\
\hline 9) Government of Sri Lanka must & Agree or Strongly agree & 32 & $8 \%$ & 7 & $3 \%$ & 39 & $5 \%$ & $X 2=7.703$ \\
\hline legalise abortion on the request of the & Disagree or Strongly disagree & 375 & $92 \%$ & 253 & $97 \%$ & 628 & $85 \%$ & $\mathrm{P}=0.006^{* *}$ \\
\hline couple. & Subtotal & 407 & $100 \%$ & 260 & $100 \%$ & 667 & $90 \%$ & \\
\hline 10) Government of Sri Lanka must & Agree or Strongly agree & 27 & $7 \%$ & 5 & $2 \%$ & 32 & $4 \%$ & $\mathrm{X} 2=7.886$ \\
\hline legalise abortion on the request of the & Disagree or Strongly disagree & 378 & $93 \%$ & 257 & $98 \%$ & 635 & $86 \%$ & $\mathrm{P}=0.005^{* *}$ \\
\hline woman. & Subtotal & 405 & $100 \%$ & 262 & $100 \%$ & 667 & $90 \%$ & \\
\hline
\end{tabular}

* Statistically significant at 95\% confidence interval

** Statistically significant at $99 \%$ confidence interval 
economic problems $\left(\mathrm{X}^{2}=11.582, \mathrm{P}=0.001\right)$, contraceptive failures $\left(\mathrm{X}^{2}=4.118, \mathrm{P}=0.042\right)$, at the request of the couple $\left(\mathrm{X}^{2}=7.703, \mathrm{P}=0.006\right)$, and at the request of the women $\left(\mathrm{X}^{2}=7.886, \mathrm{P}=0.005\right)$. In other words, the result indicates that the males are more reluctant to accept legalising abortion for the conditions which are within the control of women. These results reveal the influence of the perceived gender roles in Sri Lankan society on abortion attitudes, where females are more responsible for managing their families and other family related matters. Considering the distribution of gender roles in Sri Lankan society, women are more sensitive towards the issues related to poor economic conditions of the family and contraceptive failures.

The respondents who did not support legalising abortion under at least five out of ten situations were directed to rank the most important reasons for not accepting legalising induced abortion in Sri Lanka. The results indicated that the respondents' decision for not accepting legally induced abortion in Sri Lanka is mainly based on religious beliefs and moral values. However, around 15 percent of females and 5 percent of males $\left(\mathrm{X}^{2}=7.294, \mathrm{P}<0.001\right)$ have selected "It will increase promiscuous behaviors" as the first reason for not accepting liberalised abortion law in Sri Lanka. Similarly, 8 percent of females and 1 percent of males $\left(\mathrm{X}^{2}=19.111, \mathrm{P}<0.001\right)$ have selected "It will encourage unmarried young people to have sex" as the first reason for not accepting liberalised abortion law. These results highlight that females tend to consider reasons related to sexual behaviors than males when making decisions on liberalising law on abortion. Similarly, female respondents ( 9 percent) tend to select the option "It is socially unacceptable" as the first reason for conservative attitudes for abortion law compared to male respondents ( 3 percent $)\left(\mathrm{X}^{2}=11.491, \mathrm{p}=0.001\right)$.

\section{CONCLUSION}

The knowledge on induced abortion and related matters of the residents in the Colombo city is average to low. Especially, their knowledge on current law on abortion in Sri Lanka is considerably low. As expected, females demonstrated a higher level knowledge on pregnancy and matters related to law on abortion compared to males. However, female residents' awareness on emergency contraceptives and consequences of induced abortion are relatively low compared to the males.

In general, the respondents' attitude towards induced abortion is conservative and shaped by cultural and moral values. Female respondents demonstrated more conservative attitudes towards induced abortion when compared to males. However, males are more reluctant to accept legalising abortion for the conditions which are within the control of women (economic reasons, contraceptive failure).

Even though discussions on amending the current abortion law to legalise abortion are underway for victims of rape and incest and in cases of fetal abnormalities, it will solve only less than 5 percent of the issue (Perera et al., 2004). However, in view of public acceptance, government may consider legalizing induced abortion for rape, incest and fetuses with lethal abnormalities. Since a majority of the respondents are against legalising abortion for other situations (e.g: economic reasons, contraceptive failure, on the request of the women), it may create social unrest and psychological problems. Thus, prevention of unplanned pregnancies and sensitisation of the society about the issue of illegal abortion through continuous awareness and advocacy campaigns will still remain as key strategies to prevent unsafe abortions in the country.

\section{ACKNOWLEDGEMENT}

The field survey team headed by Ms. Chamari Kumari De Thabrew, Prof. Indralal De Silva, Prof. Wanigasundara, Prof. S. Samitha, Prof. W. M. K. Wijethunga, Dr. Sumithra Tissera, Ms. Natasha de Rosayro, Mr. Duminda Rajakaruna, Mr. Kalhara Senadhira, Dr. Thiloma Moonasinghe, Dr. Heshan Wickramasinghe, Mr. Mahinda Deshapriya, Mr. R. V. P. Rajapakshe, Mr. Thilina Wickramarathne, Mr. Chaminda Hettiarachchi, Ms. Mallika Samarawickrama and Mr. Krishan Yogeshwaran, Dr. Karthik Sirinivasan and Ms. Nilanthi Kumari Weerasinghe.

\section{REFERENCES}

Abeykoon, A. T. P. L. (2012) Estimates of Abortion Rate in Sri Lanka using Bongaarts Model of Proximate Determinants of Fertility, Colombo: The United Nations Population Fund.

Arambepola, C. and Rajapakshe, C. L. (2014) Decision making on unsafe abortions in Sri Lanka: A case-control study [Online] Available from: https://www.ncbi.nlm.nih.gov/pmc/articles/ PMC4280739/ [Accessed: $13^{\text {th }}$ September 2015].

Arambepola, C. and Rajapakshe, C. L. (2014) Hospital Based Study on Unintended Pregnancies in Sri Lanka, Colombo: United Nations Population Fund.

Cater, J. S., Cater, S. and Dodge, J. (2009) Trends in Abortion Attitudes by Race and Gender: A Reassesment Over a Four Decade Period, Journal of Sociological Research, 1(1), pp: $1-15$.

Dalvie, S., Batua, A. and De Silva, I. W. (n.d.) A study of knowledge, attitudes and understanding of legal professionals about safe abortion as a women's right. [Online] Available 
from: http://asap-asia.org/wp-content/uploads/2015/01/ Philippines_Abortion_Booklet_Update.pdf [Accessed: $5^{\text {th }}$ July 2014].

De Silva, I. W. (1997) The Practice of Induced Abortion in Sri Lanka, Massachusetts: Harvard School of Public Health.

Department of Census and Statistics (2009) Demographic and Health Survey - 2006 / 2007, Colombo: Department of Census and Statistics.

Department of Census and Statistics (2012) Census of Population and Housing - 2011, Colombo: Department of Census and Statistics.

Department of Economic and Social Affairs- Statistics Division, United Nations Secretariat (2005) Designing Household Survey Samples: Practical Guidelines [Online] Available at: https://unstats.un.org/unsd/demographic/sources/surveys/ Handbook23June05.pdf [Accessed: $15^{\text {th }}$ January 2013].

Department of Election (2012) Voting list of Thimbirigasyaya Divisional Secratariate Division, Colombo: Department of Election.

Family Health Bureau (2014) Annual Report on Family Health - 2013, Colombo: Family Health Bureau.

Finlay, A. B. (1981) Sex Differences in Correlates of Abortion Attitudes among College Students, Journal of Marriage and Family, 43(3), pp: 571-582.

DOI: https://doi.org/10.2307/351758

Hewage, P. (1999) Opinions of Health Professionals on Induced Abortion in Sri Lanka, PhD thesis, Galle: Faculty of Medicine, University of Ruhuna.

Lucinda, J. and Cynthia, P. (2009) Gender role attitudes and attitudes to abortion: Are there gender differences?, The Social Science Journal, 46(3), pp: 493-505.

DOI: https://doi.org/10.1016/j.soscij.2009.02.006

Mosby's Medical Dictionary (2008) 8th Ed., Amsterdam: Elsevier Health Sciences.

Narendra, A. (2010) Implication of sex and education on abortion attitudes; A cross sectional analysis [Online] Available from: https://ir.library.oregonstate.edu/concern/defaults/ bz60cx91t?locale $=$ en [Accessed: $10^{\text {th }}$ December 2013].

Perera, J., De Silva, I. W. and Gange, H. (2004) Knowledge behavior and attitude on induced abortion and family planning among Sri Lankan women seeking termination of pregnancy, Ceylon Medical Journal, 49(1), pp: 7-14.

Rajapakse, L. C. (2000) Estimates of Induced Abortion using RRT Technique, Colombo: s.n.

Rajapakshe, L. and De Silva, I. W. (2000) Profile of women seeking abortion, Colombo: University of Colombo.
Rock, A. J., Jones, I. and Howard, W. (ed.) (2008) Te Linde's Operative Gynecology, s.1.:s.n.

Senanayake, L., Willatgamuwa, S. and Jayasinghe, K. (2008) Reducing the burden of unsafe abortion in Sri Lanka - A situation analysis and plan of action, Colombo: The Family Planning Association of Sri Lanka.

Senanayake, L. (2009) Prevention of unsafe abortion in Asia Ocenia Region, s.1.: Asia Ocenia Federation of Obstetrics and Gynecology.

Senanayake, L., Willatgamuwa, S., Moonasinghe, L. and Tissera, S. (2012) Unwanted / Unplanned pregnancies and their aftermath., Colombo: The Family Planning Association of Sri Lanka in collaboration with the College of General Practitioners of Sri Lanka.

Simpson, B., Dissanayake, M. V. H., Wickramasinghe, D. and Jayasekara, W. R. (2003) Prenatal testing and pregnancy termination in Sri Lanka; Views of medical students and doctors , Ceylon Medical Journal, pp: 129-132.

Sri Lanka (1883) Sri Lanka Penal Code, Section 303, [Online] Available from: http://www1.umn.edu/humanrts/research/ srilanka/statutes/Penal_Code.pdf[Accessed: $15^{\text {th }}$ August 2015].

Suranga, S., Tissera, S., Kaluarachchi, A. and Sajeemala, W. G. (2016) An Assessment of Knowledge and Attitudes Regarding Induced Abortion Among Clients Attending Clinics of the Family Planning Association of Sri Lanka, Colombo, Annual Research Symposium - 2016, Colombo: University of Colombo.

Thalagala, N. (2010) Economic perspectives of unsafe abortions in Sri Lanka, Colombo: The Family Planning Association of Sri Lanka.

Thalagala, N. (2010) Unsafe abortions in Sri Lanka -facts and risk profile, Journal of the Community Physicians of Sri Lanka, 15(1), pp: 1-12.

The American Heritage Stedman's Medical Dictionary (2002) Induced abortion. [Online] Available from: http://dictionary. reference.com/browse/inducedabortion [Accessed: $08^{\text {th }}$ March 2014].

Walzer, S. (1994) The Role of Gender in Determining Abortion Attitudes, Social Science Quarterly, 75 (3), pp: 687-693.

Wickramasinghe, H. K., Wickramasinghe, I. S., Atukorala, R. K. and Weerasurendera, B. (2009) Attitudes on abortion among a group of Sri Lankan medical students, Colombo: Faculty of Medicine, University of Colombo.

World Health Organization (2011) WHO Sexual and Reproductive Health Strategy 2010 - 2015, Geneva: WHO Document Production Services.

World Health Organization (n.d.) Preventing Unsafe Abortion [Online] Available from: http:/www.who.int/ reproductivehealth/topics/unsafe_abortion/hrpwork/en/ [Accessed: 25 ${ }^{\text {th }}$ June 2015]. 